\title{
Moya-Moya's Disease. Presentation of a Case and Review of Literature
}

\author{
Gerardo Villegas-López ${ }^{1 *}$, Madelinne Granados Macías $^{2}$ and Adrián Amaya Echeverri ${ }^{3}$ \\ ${ }^{1}$ Pediatric Neuroradiologist, Private Children's Hospital Consultant, Mexico \\ ${ }^{2}$ Pediatric Radiologist, Mexico \\ ${ }^{3}$ Resident Physician of Pediatrics, Mexico \\ *Corresponding author: Gerardo Villegas-López, Pediatric Neuroradiologist, Medical Sub-Director El Chopo laboratory, \\ Private Children's Hospital, Star Medica. Radiology and Image Service, Mexico
}

\begin{tabular}{|c|c|}
\hline ARTICLE INFO & ABSTRACT \\
\hline Received: 幽 July 21, 2020 & \multirow{4}{*}{$\begin{array}{l}\text { Moya Moya's disease is considered to be progressive occlusive cerebral } \\
\text { vasculopathy, characterized by stenosis or occlusion of the supraclinoid segment of } \\
\text { the internal carotid artery, the middle cerebral artery and the anterior cerebral artery, } \\
\text { on one or both sides. This disease mainly affects the Asian population and the female } \\
\text { sex. The etiology is unknown, it is postulated that it could be related to a chromosomal } \\
\text { alteration } 8 \mathrm{q} 23 \text { and } 12 \mathrm{p} 12 \text {. }\end{array}$} \\
\hline Published: & \\
\hline Citation: Gerardo & \\
\hline Madelinne Granados Macías, Adrián & \\
\hline Amaya Echeverri. Moya-Moya's Disease. & Summary \\
\hline $\begin{array}{l}\text { Presentation of a Case and Review of } \\
\text { Literature. Biomed J Sci \& Tech Res 29(2)- }\end{array}$ & It presents clinical case of a male 8 years 3 months, attended at the Star Medica \\
\hline 2020. BJSTR. MS.ID.004766. & $\begin{array}{l}\text { Private Children's Hospital in the CDMX, with suggestive clinical data of occlusive } \\
\text { cerebral vasculopathy. A simple, proven MRI shows suggestive findings of morphological }\end{array}$ \\
\hline $\begin{array}{l}\text { Keywords: Moya-Moya Disease, Occlusive } \\
\text { Vasculopathy }\end{array}$ & $\begin{array}{l}\text { disorders in the supraclinoid segment of both internal carotid arteries, suggestive of } \\
\text { Moya-Moya's disease. }\end{array}$ \\
\hline
\end{tabular}

\section{Presentation of the Clinical Case}

Male 8 years 3 months, Mexican nationality. History of importance Down syndrome. Hospitalization a year ago for diagnosis of encephalitis, which left sequelae of right hemiparesis by the etiological agent herpes virus. The current condition begins two days prior to admission, with generalized abnormal movements referred to by the mother as abnormal, continues with dyslalia and dysarthria. Physical examination shows decreased strength of right chest limb 4/5, left chest member 5/5. Encephalogram is performed where normal is reported [1-5]. Two days later continue with sialorrhea and inability to swallow for 20 seconds. Simple Magnetic Resonance Is Performed (Figures 1-3) establishing imaging diagnosis of Moya-Moya disease.

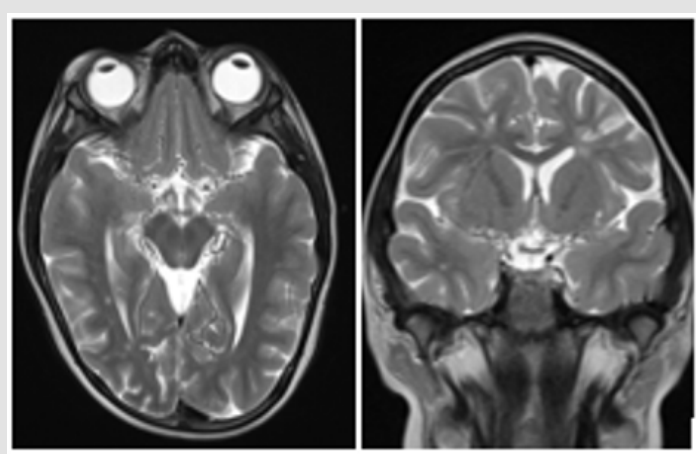

Figure 1: (A, B) Magnetic resonance imaging enhanced in axial and coronal flat T2 sequences where abnormal vascular network is observed in the topography of the middle cerebral artery path bilaterally. 


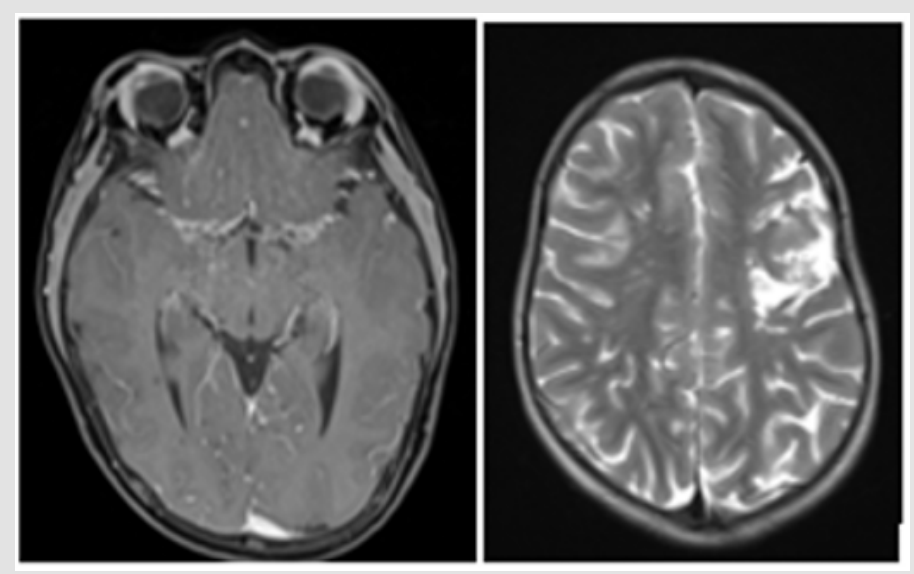

Figure 2: (C) Magnetic resonance enhanced in T1 proven phase where the same collateral network of vessels is observed in region of both supraclinoid arteries. (D) Image in Axial enhanced in T2 which attracts attention area of encephalomalacia in front and temporal right region.

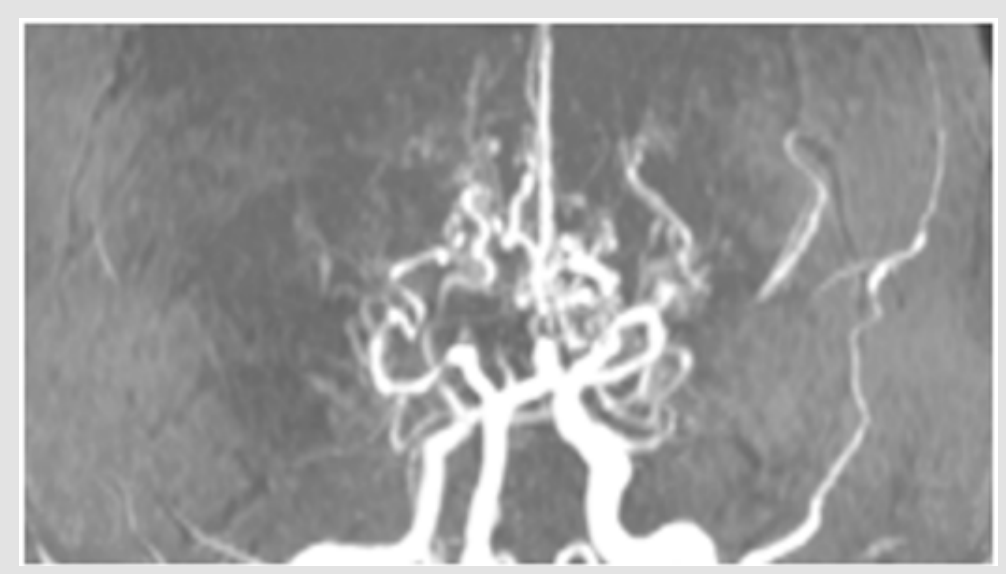

Figure 3: Angio RM. The caliber of the vessels of a part of the arterial circle of the cranial base (Polygon of Willis) with collateral network in "fumarole" and absence of distal vascularity in M4 segment of the middle cerebral artery.

\section{Discussion}

Moya-Moya disease is a rare idiopathic, non-atherosclerotic or inflammatory and non-amyloid cerebrovascular process. It is characterized by progressive stenosis and chronic occlusion of the internal carotid arteries (supraclinoid segment) as well as the anterior and middle cerebral arteries. As a result, a collateral network of vessels is formed, characteristic of the pathology. Vascular engagement is generally bilateral, although unilateral cases in pediatric age and adulthood are described. The first description of the disease was made in Japan in 1957 by Takeuchi and Shimizu, however, it was named only as Moya Moya's disease in 1969 BY Suzuki and Takaku to its appearance similar to cigarette smoke (fumarola) detected in angiographic studies [6-8].

Diagnosis can be supported by several neuroimaging studies such as digital angiography, Angio Resonance (Angio MRI) Figure $3^{\text {rd }}$ Or Single Photon Emission Tomography (SPECT) $[9,10]$. Angio $\mathrm{RM}$ is a noninvasive method that is also useful for diagnosis, even in asymptomatic patients. When an MRI clearly demonstrates stenosis or occlusion in the terminated portion of the internal carotid artery and/or proximal portion of the posterior cerebral artery or mean brain, abnormal collateral is observed in the vicinity of occlusion, conventional cerebral angiography is not indispensable $[11,12]$. The arterio-hard-synangiosis surgical technique or indirect technique was performed, with wide opening of the dura mater in opposition to the superficial temporal artery and wide surrounding galeal tissue, with fixation of this tissue to the pyamadre of the cerebral convexity, to which small windows are made and the piamadre is removed to achieve a closer contact between the donor artery and the cerebral parenchyma (Figures 4-8). 


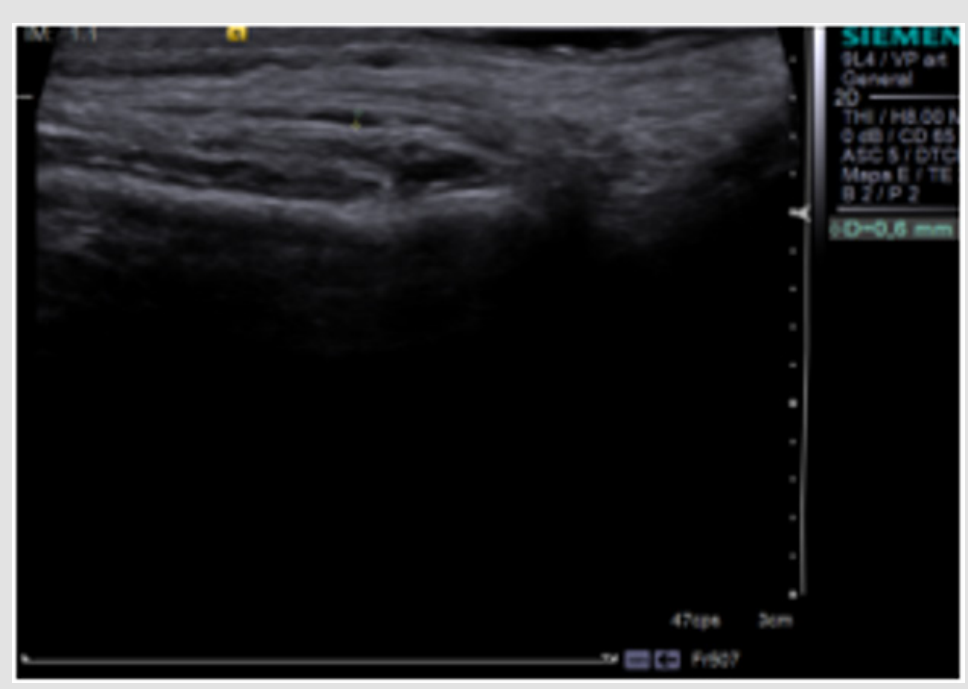

Figure 4: Doppler Ultrasound to evaluate indirect revascularization of left surface temporal artery.

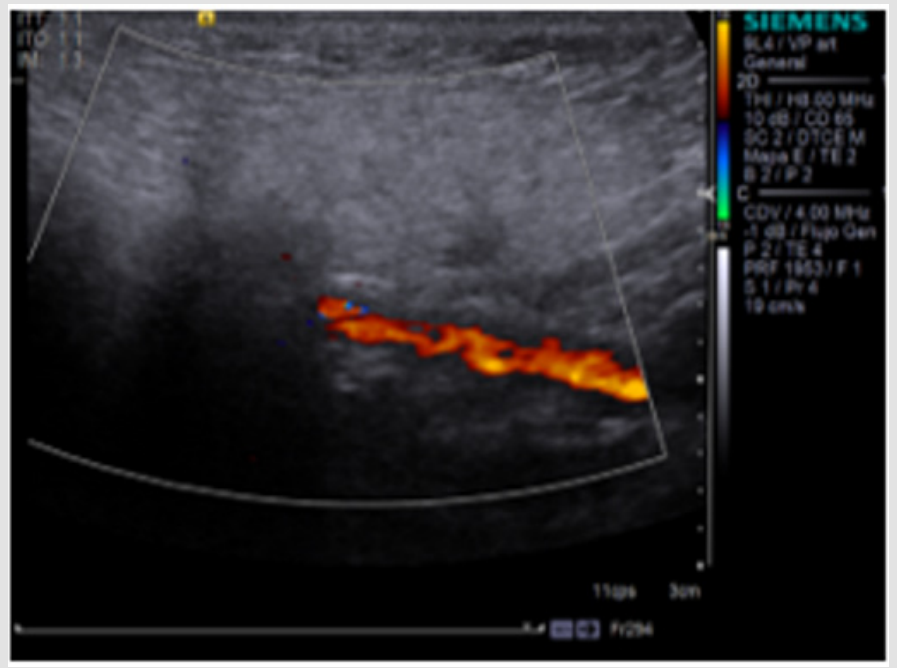

Figure 5: Doppler Ultrasound to evaluate indirect revascularization of left surface temporal artery.

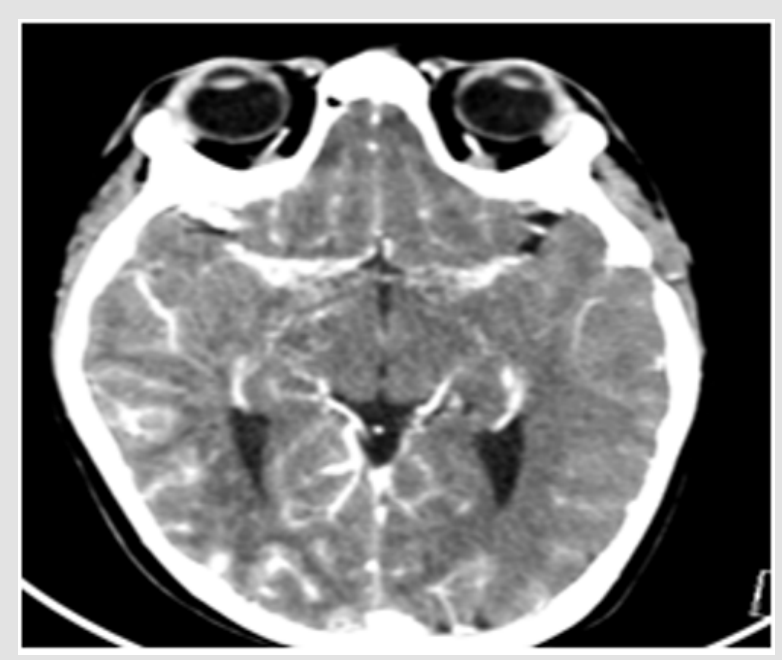

Figure 6: Post-surgical control computed tomography. Increased cortical peripheral vascularized is seen in M4 segment, after revascularization. 


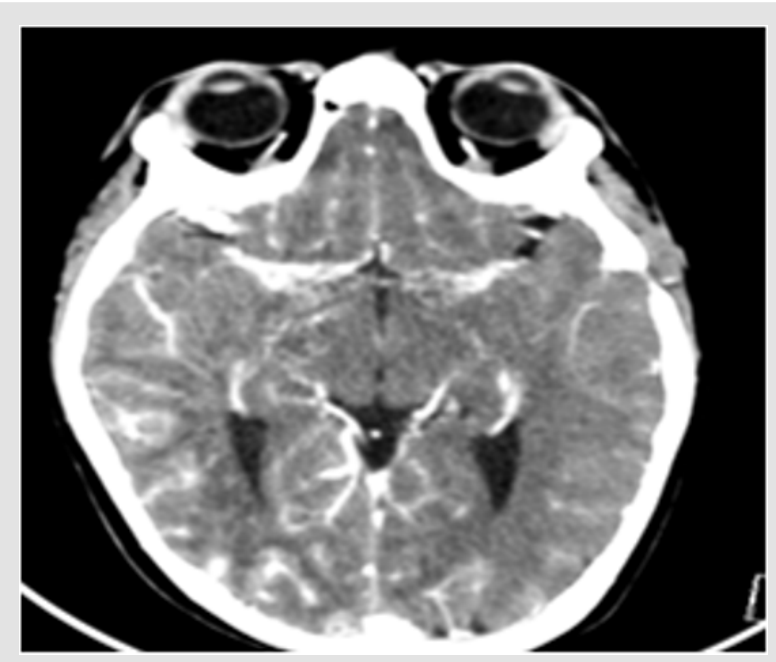

Figure 7: Post-surgical control computed tomography. Increased cortical peripheral vascularized is seen in M4 segment, after revascularization.

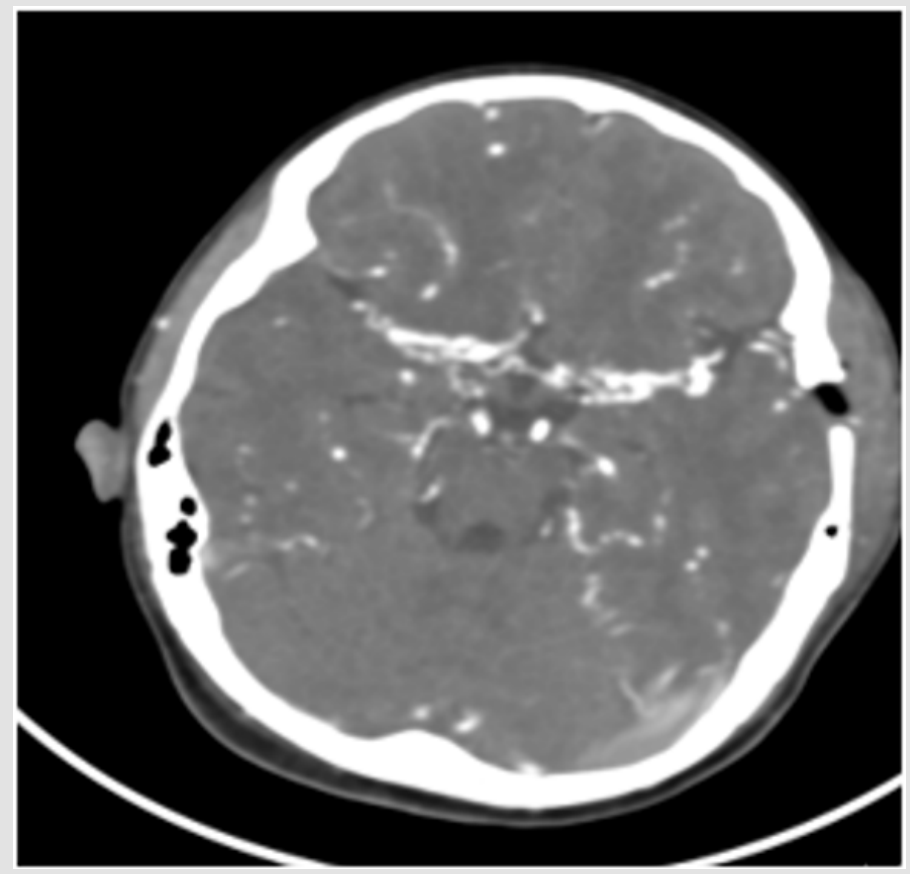

Figure 8: Post-surgical control computed tomography. Increased cortical peripheral vascularized is seen in M4 segment, after revascularization.

\section{Conclusion}

Takeuchi and Shimizu in Japan in 1957, considered it a bilateral hypogenesia of the internal carotid arteries. Later, in 1969, Suzuki and Takaku (4) used the name Moya-Moya to refer to this process, a term that describes the appearance In the search for a defined etiology, one of some forms of vasculitis has been found, developing thickening of the vascular intimate, sometimes after a previous infectious process, a fact frequently observed in Moya-Moya disease. It is the first case of Moya-Moya Disease at least in the last 5 years in the Private Children's Hospital. In this patient it can be characterized as a child with important risk factors such as Down syndrome. There are both clinical and image characteristics that make you think about Moya Moya disease.

\section{Conflict of Interest}

No conflict of interest.

\section{References}

1. Powell FC, Hanigan WC, Mc Cluney KW (1994) Subcortical Infarction in Children. Stroke 25: 117-121.

2. Schoenberg BS, Mellinger JF, Schoenberg DG (1978) Cerebrovascular disease in infants and children: a study of incidence, clinical features, and survival. Neurology 28: 763-768. 
3. Takeuchi K, Shimizu K (1957) Hipogenesis of bilateral internal carotid arteries. No To Shinkei 9: 37-43.

4. Suzuki J, Takaku A (1969) Cerebrovascular "Moya-Moya" disease: disease showing abnormal net-like vessels in base of brain. Arch Neurol 20: 288-299.

5. Miyamoto S, Kikuchi H, Karasawa J, Nagata Y, Ikota T (1984) Takeuchi S. Study of the posterior circulation in Moya-Moya disease. J Neurosurg 61: 1032-1037.

6. Aoyagi M, Ogami K, Matsushima Y, Shikata M, Yamamoto M, et al. (1995) Human leukocyte antigen in patients with Moya-Moya disease. Stroke 26: 415-417.

7. Pavlakis SG, Verlander PC, Gould RJ, Strimling BC, Auerbach AD (1998) Fanconi anemia and Moya-Moya: Evidence for an association. Neurology 45: 998-1000.

ISSN: 2574-1241

DOI: $10.26717 /$ BJSTR.2020.29.004766

Gerardo Villegas-López. Biomed J Sci \& Tech Res

(C) This work is licensed under Creative

Submission Link: https://biomedres.us/submit-manuscript.php
8. Lutterman J, Scott M, Nass R, Geva T (1998) Moya-Moya syndrome associated with congenital heart disease. Pediatrics 101: 57-60.

9. Masuda J, Ogata J, Yutani Ch (1993) Smooth muscle cell proliferation and localization of macrophages and $\mathrm{T}$ cells in the oclusive intracranial major arteries in Moya-Moya disease. Stroke 24: 1060-1067.

10. Suzui H, Hoshimaru M, Takahashi J, Kikuchi H, Fukumoto M, et al. (1994) Immunohistochemical reactions for fibroblast growth factor receptor in arteries of patients with Moya-Moya disease. Neurosurgery 35: 20-25.

11. Kurokawa T, Tomita S, Ueda K, Narazaki O, Hanai T, et al. (1985) Prognosis of oclusive disease of the circle of Willis (Moya-Moya disease) in children. Pediatr Neurol 1: 274-277.

12. Kwak R, Ito S, Yamamoto N, Kadoya S Significance of intracranial aneurysms associated with Moya-Moya disease (part I): differences between intracranial aneurysms associated with Moya-Moya disease and usual saccular aneurysms- review of the literature. Neurol M.

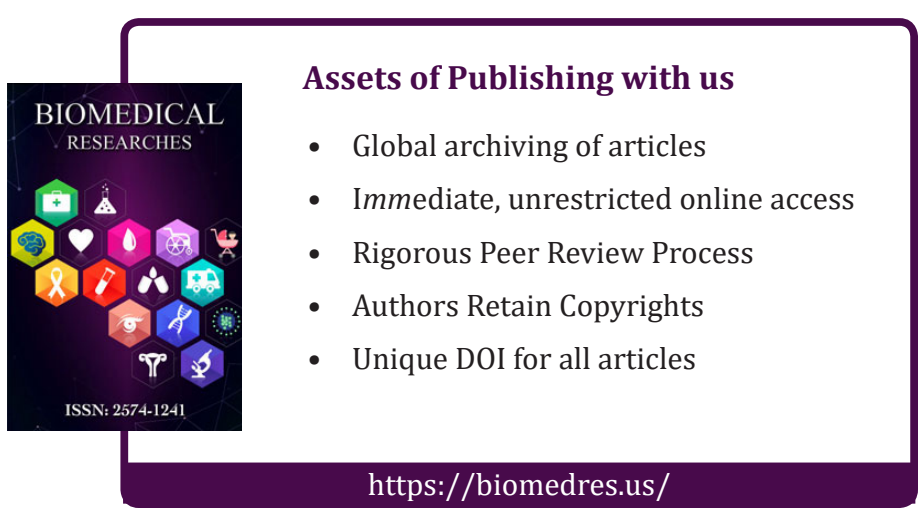

